\title{
AS ECONOMIAS POLÍTICAS NACIONAIS VIVENCIADAS POR GEORG FRIEDRICH LIST
}

\section{THE NATIONAL POLITICAL ECONOMIES EXPERIENCED BY GEORG FRIEDRICH LIST}

\author{
Flavia Maria Morais Lazzaretti \\ Júlio Eduardo Rohenkohi*
}

\begin{abstract}
RESUMO: O presente artigo - por meio de pesquisa fundamentada na leitura das principais obras de Georg Friedrich List, Esboço da Economia Política Americana e Sistema Nacional de Economia Política, e em contribuições recentes de historiadores econômicos - tem como objetivo principal descrever a trajetória de desenvolvimento de Inglaterra, Alemanha e Estados Unidos da América do século XVIII a meados do século XIX. Para alcançar este objetivo, foi efetuada uma comparação entre as descrições e interpretações dos diferentes autores. Verificou-se uma significativa similaridade entre os conteúdos apresentados por List $(1983,2009)$ e as interpretações dos demais historiadores econômicos quanto à evolução das forças produtivas nacionais. Os complementos aos relatos de List dão conta de que: a) a Inglaterra era fonte de transbordamento de conhecimentos produtivos e capital para as nações mais atrasadas; b) a proteção tarifária não era tão importante para o desenvolvimento nacional como supunha List (1983); e, c) os trabalhos de Tilly (1978) e Philip (1980) proporcionam informações objetivas que permitem precisar que a agricultura alemã teve a sua produção condicionada a normativas feudais da Idade Média até a metade do século XIX. Dentre os principais aspectos das economias nacionais vivenciadas por List estão a nação e as forças produtivas, interligando os setores agrícola, industrial e comercial.
\end{abstract}

PALAVRAS-CHAVE: List. Nação. Forças produtivas.

ABSTRACT: This article - through research based on the reading of the major works of Georg Friedrich List, Economy American Policy Outline and National Economic Policy System, and recent contributions of economic historians - has as the main aim to describe the development path of England, Germany and the United States of America from the eighteenth century to the midnineteenth century. To achieve this aim was made a comparison between the descriptions and interpretations of different authors. There was a significant similarity between the content presented by List $(1983,2009)$ and the interpretations of other economic historians regarding the development of national productive forces. In additions to List's reports realize that: a) England was the overflowing source of productive knowledge and capital to the most backward nations; b) tariff protection was not as important to national development as was supposed by List (1983); and c) Tilly's (1978) and Philip's (1980) works provide objective information that allows to specify that German agriculture had its production conditioned by feudal norms from the Middle Ages to the mid-nineteenth century. Among the main aspects of national economies are the nation and the productive forces experienced by List, linking the agricultural, industrial and commercial sectors.

KEYWORDS: List. Nation. Productive forces.

\footnotetext{
* Mestre em Economia e Desenvolvimento pelo Programa de Pós-Graduação em Economia e Desenvolvimento da Universidade Federal de Santa Maria (UFSM). Contato: flaviamlazzaretti@gmail.com.

** Professor doutor adjunto do Departamento de Ciências Econômicas e do Programa de Pós-Graduação em Economia e Desenvolvimento da Universidade Federal de Santa Maria (UFSM). Contato: julioroh@gmail.com
} 


\section{Introdução}

A importância da Nação como instância de debate e execução de estratégias de desenvolvimento econômico é tema de investigação acadêmica há mais de século. Um dos recortes analíticos mais recentes e importantes a tocar na temática é o Sistema Nacional de Inovação. O conceito foi criado em meados dos anos de 1980, quando tomava corpo a tese sobre a aceleração da globalização econômica. A capacidade inovativa de um país ou região é vista como resultado das relações entre os atores econômicos, políticos e sociais, e reflete condições culturais e institucionais próprias. É reconhecido que o conceito de Sistemas Nacionais de Inovação é tributário das ideias de Georg Friedrich List (FREEMAN, 2004, p. 541-569; CASSIOLATO; LASTRES, 2005, p. 34-45). A produção do economista germânico também influenciou a produção de autores ligados à Comissão para a América Latina e o Caribe (CEPAL). A visão cepalina aponta que a ruptura com um padrão de especialização na produção e exportação de produtos primários ocorreria a partir da incorporação e disseminação da industrialização nas economias nacionais (BIELSCHOWSKY, 2000; CASSIOLATO; LASTRES, 2005; FONSECA, 2000; COSTA, 2012).

Georg Friedrich List nasceu em 1789, em Wurttemberg, na Alemanha e, em 1817, ingressou muito jovem na administração pública na localidade de Wagenheim. Em 30 de novembro de 1846, aparentemente por suicídio, morreu em Kufstein, Alemanha. Sua obra e vida se integraram em propostas revolucionárias na forma de ação contínua em diferentes setores e países. A magnitude da vida de List pode ser dimensionada nos estudos, nos empreendimentos e na política, como agitador, jornalista, homem de negócios e teórico (BUARQUE, 1979, p. VII).

List (1983) discutia medidas para o desenvolvimento de algumas nações atrasadas mediante a harmonia no desenvolvimento da indústria, agricultura, comércio e demais serviços, assim como do poder político e riqueza da nação. Nesse aspecto, ocorreu, por parte do autor, uma análise crítica a alguns economistas clássicos, como Smith, Ricardo e $\mathrm{Say}^{45}$, que não atribuíram tanta atenção às especificidades locais, à técnica e às aptidões intelectuais das pessoas no crescimento das nações.

List difere dos economistas clássicos por trazer uma perspectiva econômica estrutural das nações, associada ao um contexto mais amplo da realidade social e global, que se baseava em uma configuração histórica e espacial. Entre suas contribuições, está a centralidade da Nação como unidade de análise e de locus do processo de desenvolvimento e o conceito de forças produtivas, as quais derivam das forças físicas e mentais das pessoas; das condições e instituições sociais, políticas e locais; das produções materiais de atividades agrícolas, industriais e comerciais. List descreve que cada nação é produtiva somente na proporção em que souber apropriar-se das conquistas das gerações anteriores e as fazer crescerem por seus próprios recursos, na medida em que as potencialidades naturais de seu território e sua posição geográfica sejam articuladas com a formação técnica do capital humano e com uma institucionalidade de propriedade tangível e intelectual que proporcionem maior valor agregado à produção. Este esforço tem de ser politicamente articulado e demanda tempo. Ao final do processo, surge uma ligação complementar entre as espécies de produtos agrícola e minerais, bem como de sua escala de fornecimento e de sua qualidade, com o processamento industrial e, por sua vez, com as áreas de especialização comercial da economia. Esta tessitura de relações técnicas e econômicas estrutura as vantagens competitivas nacionais.

\footnotetext{
45 Para os clássicos, o interesse individual corresponde ao interesse geral, e deve-se deixar plena liberdade de ação aos interesses privados no sistema para obter, como consequência, a satisfação do interesse do indivíduo e da sociedade. O indivíduo é o único apto para discernir e buscar satisfação de seu próprio interesse. A especialização produtiva e as vantagens competitivas regionais ou nacionais emergem sem maiores explicações de sua constituição, decorrem de posição geográfica e interesse espontâneo das pessoas, surgem como elementos dados a determinar as especializações produtivas e comerciais das nações.
} 
Para List (1983), a abordagem cosmopolita dos autores clássicos - aquela que analisa uma economia mundial aberta e com especialização das produções nacionais segundo vantagens comparativas produtivas e a despeito das diferenças de desenvolvimento entre as nações -, se origina da suposição de que todas as nações da terra formam uma única sociedade igualitária, enquanto a Economia Política relevante é a doutrina de como determinada nação, na situação atual do mundo e nas suas próprias relações nacionais específicas, pode manter e melhorar suas condições econômicas.

Introduz-se o pensamento de List por meio de uma releitura das trajetórias de desenvolvimento das três nações às quais ele dedicou mais atenção. Objetiva-se identificar aspectos centrais da trajetória de desenvolvimento de Inglaterra, Alemanha e Estados Unidos da América entre o início do século XVIII e a metade do século XIX. Acrescentam-se aos relatos de List $(1983,2009)$ descrições de autores contemporâneos que se debruçaram sobre a história dessas nações a fim de obter um quadro mais completo dessas economias nacionais do que o originalmente apresentado.

$\mathrm{Da}$ produção da obra ${ }^{46}$ de List à contemporaneidade, os estudiosos de história econômica coletaram novas informações sobre a indústria, a agricultura e o comércio das nações para o período investigado. Novas informações, organizadas com um distanciamento maior aos eventos, de modo a observá-los após a repercussão total de seus efeitos, trazem a oportunidade de rever as trajetórias de desenvolvimento nacionais e descrevê-las com maior robustez e serenidade. Mesmo sem exaurir a cobertura do tema, a descrição das trajetórias de desenvolvimento com informações complementares e olhares modernos renova a comunicação e contribui para o reestudo deste economista na medida em que é facilitada a apreensão de suas ideias.

List $(1983,2009)$ argumentou reiteradas vezes que o poder e a riqueza de uma nação decorrem da concatenação harmônica entre os setores agricultura, indústria e comércio. $\mathrm{O}$ amálgama entre os setores é proporcionado pelo desenvolvimento intelectual das pessoas, pela rede de transportes e comunicação e pelas iniciativas governamentais. $O$ desenvolvimento das forças produtivas seria percebido pela coordenação virtuosa entre os três setores. O objeto da comparação foi delimitado por uma noção operacional de desenvolvimento ${ }^{47}$, especificada para este trabalho, ou seja, o desenvolvimento ocorre quando há aumento de produção e renda a partir da organização produtiva entre os setores econômicos agricultura, indústria e comércio. Como contrapartida desta noção de desenvolvimento, selecionaram-se as informações colhidas nos diferentes autores consultados por setor econômico - agricultura, indústria e comércio. A trajetória de desenvolvimento é a sequência de eventos aos quais é atribuída contribuição para os acréscimos de produção e renda nacional.

O método utilizado por List é histórico-comparativo. O próprio List afirma que, além das experiências históricas, conduziu sua obra pela confluência entre a teoria e a prática para tornar a Economia Política mais compreensível aos leitores: "Esse livro da vida real, estudei-o com seriedade e diligência, comparando-o com os resultados dos meus estudos, experiência e reflexões anteriores" (LIST, 1983, p. 5). List combinava a descrição histórica com a observação da situação efetiva das nações em suas estadas em diferentes países da Europa e nos Estados Unidos, realizando estudos comparados de trajetórias nacionais.

\footnotetext{
${ }^{46}$ As principais obras de List são 1) Outlines of American Political Economy, que teve a sua primeira edição publicada em 1827, nos Estados Unidos da América, cuja versão utilizada foi a traduzida para o português como Esboço de Economia Política Americana, e incluída no livro Cartas da Economia Nacional Contra o Livre Comércio, de 2009; e 2) Das Nationale System Der Politischen Ökonomie, com primeira edição publicada em 1841, na Alemanha, cujas versões consultadas foram Sistema Nacional de Economia Política, traduzida para o português em 1983 e 1986, e a traduzida para o inglês The National System of Political Economy, publicada em 1846.

47 Schumpeter (1982) propôs o desenvolvimento econômico como a mudança qualitativa da produção por meio de transformações incrementais nos processos produtivos, na qualidade dos produtos, no tipo de materiais empregados na produção e na organização dos modelos de negócios. O que moveria os empreendedores a envidarem esforços de aprendizagem produtiva seria a busca do lucro extraordinário. Esta conceituação de desenvolvimento se aproxima da abordagem de List, embora List não tenha discutido o papel do empreendedor tal como Schumpeter.
} 
Quando a pesquisa é vinculada a uma abordagem histórico-comparativa, ela é caracterizada por "um exame detalhado de um aspecto de um episódio histórico com o intuito de desenvolver ou testar explicações que podem ser generalizadas para outros eventos" (GEORGE; BENNETT, 2005). Conforme os autores, o método históricocomparativo é usado para comparações de grupos no presente; para comparações de grupos no passado; para comparações entre os existentes e os do passado; para comparações entre sociedades de iguais ou de diferentes estágios de desenvolvimento. Nesta perspectiva de aperfeiçoamento do conhecimento, uma releitura da trajetória de estruturação de sistemas nacionais importantes para as argumentações de List $(1983,2009)$ é relevante. Para tanto, utiliza-se a descrição de outros autores de história econômica ${ }^{48}$, cada qual com o seu problema e método de investigação, porém oferecendo como ponto comum com List (1983) relatos da organização produtiva dos três setores econômicos agricultura, indústria e comércio -, para o mesmo grupo de países e o mesmo período (séculos XVIII e XIX) ${ }^{49}$.

$O$ artigo conta, além desta introdução, duas seções. A primeira versa sobre a trajetória de desenvolvimento das nações na obra econômica de List, a Inglaterra, os Estados Unidos e a Alemanha, descrevendo a agricultura, o comércio e a indústria. A seguinte apresenta as considerações finais.

\section{A unidade política e econômica da Inglaterra}

Cabe ressaltar que séculos antes de a Inglaterra se consolidar como nação rica no século XVIII, ela era extremamente dependente do comércio estrangeiro. Os ingleses aprenderam a realizar o comércio seguindo o modelo da Liga Hanseática, uma aliança de cidades mercantis de cultura alemã entre os séculos XII e XVII. Da vida em comum levada pelos cidadãos de cidades próximas, originou-se um espírito pelo progresso nas artes e na manufatura. Reforçadas pelo poder de liberdade e da indústria florescente, porém expostas aos ataques de piratas de terra e mar, as cidades marítimas do norte da Alemanha sentiram a necessidade de uma união mútua para sua proteção e defesa. Com esse objetivo, Hamburgo e Lübeck formaram uma liga que englobava as cidades do Mar Báltico e do Mar do Norte, totalizando oitenta e cinco cidades (LIST, 1983).

A Liga estabeleceu uma política comercial comum. Os hanseáticos sabiam que a criação e a manutenção de um vasto comércio marítimo necessitavam de proteção. Para tanto, criaram uma poderosa esquadra naval e sancionaram uma lei pela qual os bens e produtos da Hansa só poderiam ser transportados por embarcações de bandeira hanseáticas e, ao mesmo tempo, fundaram grande número de postos de pesca. Apesar de tantos feitos, o comércio dessas cidades hanseáticas não era um comércio "nacional", não era baseado no desenvolvimento perfeito dos poderes internos de produção, nem era sustentado por um poder político adequado. Os vínculos que mantinham unidos os

\footnotetext{
${ }^{48}$ Especificamente, Philip (1980), Hobsbawm (1961, 1977), Tilly (1989), Chang (2004) e Freeman (2008). A escolha dos autores ocorreu de duas maneiras: primeiramente, os autores Philip (1980), Hobsbawm (1977) e Tilly (1989) são conceituados historiadores econômicos e explicitam a conjuntura das nações aproximadamente no mesmo período sobre o qual List se debruçou; segundo, Chang (2004) e Freeman (2008), por serem autores contemporâneos que resgatam a argumentação de List. Cada um destes autores persegue objetivos distintos uns dos outros em seus trabalhos, e comparar obras inteiras não faria sentido. Selecionaram-se as passagens utilizadas para compatibilizar as informações e organizar a descrição, delimitando-se o período histórico e o objeto de interesse. Foram selecionadas partes dos trabalhos que cobriam período e objeto correspondente a List (1983; 2009) e a descrição da organização da produção agrícola, industrial e comercial.

49 Para o período histórico discutido, buscou-se nos diversos autores informações sobre o desenvolvimento dos países em questão para o intervalo de cerca de um século analisado por List, entre o século XVIII e meados do século XIX. Alguns estudos cobrem parcialmente o período. Em algumas obras, inclusive de List, são referenciadas informações anteriores a este período: nestes casos, tais informações foram incluídas apenas quando fundamentais para compreender os processos do período de interesse.
} 
membros da Liga Hanseática eram muito fracos, a disputa entre eles pelo poder tomava o lugar do patriotismo (LIST, 1983).

A Liga promoveu o comércio com distintas nações, produziu e comercializou vários produtos manufaturados com outras nações. A Inglaterra, por sua vez, forneceu lã, estanho, couro cru, manteiga e outros produtos minerais e agrícolas para os hanseáticos, recebendo em troca os bens manufaturados. Após manufaturarem as matérias-primas inglesas e continentais, os hanseáticos trocavam tecidos e roupas e outros artigos por produtos manufaturados orientais. Foi a partir desse modelo que os ingleses se deram conta de que podiam manufaturar a sua própria lã. Atraíram tecelões flamengos e, já com certa quantia de tecelões produzindo internamente, os ingleses proibiram o uso de qualquer tecido estrangeiro. Consequentemente, a indústria inglesa de lã desenvolveu-se e sua capacidade produtiva exerceu uma influência a todo comércio exterior (LIST, 1983).

List (1986) ressalta que a Inglaterra, no início do século XVIII, diferente da Liga Hanseática, possuía uma unidade nacional e poder para promover o crescimento na agricultura e na manufatura. As fontes da grandeza industrial e comercial foram identificadas na criação de ovelhas e na manufatura da lã.

\section{A agricultura britânica}

Até o início do século XVIII, os nobres na maioria dos países europeus não reconheciam outra maneira de utilizar suas propriedades rurais do que caçando animais. $A$ inovação da aristocracia inglesa de criar ovelhas implicou um significativo desenvolvimento econômico na medida em que contribuiu para o aprimoramento dos métodos da agricultura e forneceu matéria-prima para a indústria de tecelagem da lã (LIST, 1986).

Ao delinear a história da Inglaterra, Philip (1980) afirma que, além da criação de carneiros naquele período, o predomínio dos proprietários neste setor favoreceu o enorme progresso nas técnicas agrícolas do país. As terras concentradas nas mãos dos senhores passaram a ser destinadas aos produtos alimentares, dentre os quais estavam as culturas de alho e do trevo, a fim de aumentar o rendimento agropecuário.

Para Hobsbawm (1977), a Inglaterra apresentava-se em um grau supremo de desenvolvimento econômico e lucro privado devido ao apoio de políticas governamentais. $O$ setor agrícola naquele período se destacava em uma relativa quantidade de proprietários com espírito comercial e já quase monopolizava a terra, que era cultivada por arrendatários empregando camponeses sem terra ou pequenos agricultores.

Hobsbawm (1977) relata que em termos de tecnologia e de investimento de capital, as mudanças nesse tempo foram provavelmente bastante modestas até a década de 1840, o período em que se pode dizer que a ciência e a engenharia agrícolas atingiram a maturidade. $\mathrm{O}$ vasto aumento na produção capacitou as atividades agrícolas britânicas na década de 1830 a fornecer $98 \%$ dos cereais consumidos por uma população duas a três vezes maior os períodos anteriores.

A agricultura já estava organizada para levar a termo suas três funções fundamentais numa era de industrialização: aumentar a produção e a produtividade de modo a alimentar uma população não agrícola em rápido crescimento; fornecer um grande e crescente excedente de recrutas em potencial para as cidades e as indústrias; e fornecer um mecanismo para o acúmulo de capital a ser usado nos setores mais modernos da economia (HOBSBAWM, 1977).

\section{A indústria}

No século XVIII, a indústria de lanifícios trabalhava a lã dos carneiros britânicos; dispunha, por conseguinte, de uma matéria-prima certa, cujo preço encontrava-se estabilizado por regulamentos corporativos (PHILIP, 1980).

Chang (2004) aborda que a Grã-Bretanha alegava ser a única que praticou o laissezfaire e se desenvolveu sem intervenção estatal. Todavia, essa política estava longe de ser 
verdade. Desde o período em que os reis Henrique VII (1485-1509) e Elizabete I (15581608) governavam o país, houve políticas de estímulo à manufatura têxtil. A nação era muito dependente da exportação de lã bruta para os Países Baixos e transformou-se numa das maiores fabricantes de lã do mundo. No reinado de Elizabete I, o país ganhou confiança suficiente na competitividade internacional da sua indústria para proibir definitivamente a exportação lã bruta. Isso, por sua vez, resultou na ruína dos Países Baixos.

A partir de então, a revolução industrial no país concentrou-se principalmente na produção de algodão e na siderurgia. Após a conquista das Índias, a Inglaterra observou uma grande quantidade de produtos vindos desse país, em particular os tecidos de seda e de algodão do Decão (vasto planalto, localizado na Índia). Os manufatureiros estavam preocupados com esta concorrência à indústria de lanifícios tradicional. A sua influência no Parlamento era suficiente para que o Estado interviesse e proibisse a importação dos produtos algodoeiros indianos. Perante a proibição de importação dos tecidos de algodão indianos, na própria Grã-Bretanha se fundaram fábricas para o tratamento de algodão bruto que continuava livremente importado. Era uma indústria nova, um produto novo, uma matéria prima que tinha de ser transformada com preços estáveis para competir com os produtos indianos (PHILIP, 1980).

O primeiro passo e o mais importante componente dessa política industrial era, claramente, a proteção tarifária. A Grã-Bretanha teve tarifas muito elevadas sobre produtos de fabricação até o final da década de 1820. A indústria de algodão indiano foi posteriormente destruída com o fim do monopólio da Companhia das Índias Orientais em 1813, ponto a partir do qual a Grã-Bretanha tornou-se um produtor mais eficiente do que a Índia (CHANG, 2004).

List (1983) argumentava que a Inglaterra acabou proibindo a importação de vários artigos que fossem prejudiciais para suas próprias fábricas, como tecidos indianos de algodão e seda. A proibição era completa e determinante. Os ingleses renunciaram a usar qualquer um desses tecidos finos indianos e de baixo custo, preferindo usar seus próprios produtos de qualidade inferior e custo mais elevado. Para competir com os indianos, incumbia aos ingleses fornecer para os países do continente europeu tecidos mais refinados e a um preço menor. Posto isto, reduziram os preços para favorecer o comércio com essas nações.

Hobsbawm (1977) aborda que a Grã-Bretanha possuía uma economia bastante forte e um Estado suficientemente agressivo para conquistar os mercados de seus competidores. Possuía uma indústria dominante, em decorrência da revolução industrial, e uma forte conjuntura econômica que permitia que se lançasse à indústria algodoeira e à expansão colonial. A indústria algodoeira britânica, como todas as outras indústrias algodoeiras, tinha originalmente se desenvolvido como um subproduto do comércio ultramarino, que fornecia sua matéria-prima e os tecidos indianos de algodão inicialmente revendidos pelos ingleses, e que posteriormente vieram a ser imitados nas fábricas britânicas.

A Inglaterra passou pelo processo de transição da produção domiciliar para a indústria têxtil. A indústria, principalmente a de lã, já era bem desenvolvida, mas a produção ainda não era baseada em máquinas e nas fábricas. Um sistema capitalista mercantil baseado no sistema putting out para fiandeiros, tecelões e produtores de tecidos artesanais era por natureza limitada com respeito à escala do maquinário e da divisão do trabalho, bem como no que se refere à coordenação e à disciplina pela força de trabalho. Foi a transição da produção domiciliar para a produção fabril que proporcionou não somente para os mecânicos, mas também para uma variedade de imaginativos empresários, a oportunidade de ingressar nestes ramos (FREEMAN, 2008).

Para Freeman (2008), a indústria têxtil de algodão foi reconhecida como tendo papel fundamental para o crescimento industrial da Inglaterra. A fonte de matéria prima foi transferida das Índias Ocidentais para as plantações escravistas dos Estados Unidos (colônia da Inglaterra). Em 1771, com a invenção das máquinas fiandeiras jenny (movidas por rodas d'água), a indústria têxtil de algodão teve um rápido crescimento. Entretanto, as máquinas jenny conseguiam fiar somente fios macios, e os empresários e inventores 
necessitavam de meios para produzir uma variedade de fios rústicos a partir de diversos tipos de fibras de algodão, e poder fazê-lo a custo e preços ainda menores. Nos anos de 1790 a 1801, foi criada uma nova fiandeira automática, cumprindo esse papel e sendo capaz de separar os melhores dos piores fios.

De acordo Freeman (2008), o surto de crescimento da indústria britânica não ocorreu em todos os ramos industriais, mas caracterizou-se pelo crescimento excepcionalmente rápido de alguns poucos líderes, sobretudo, a indústria têxtil de algodão, e, em menor medida, a metalurgia de ferro. A participação da primeira no total do valor adicionado pela indústria cresceu de 2,6\% em 1770 para 17\% em 1801. Isso revela uma rápida e extraordinária mudança da estrutura industrial. Nas décadas iniciais da Revolução Industrial, conforme a Tabela 1.

Tabela 1 - Crescimento setorial do produto industrial na Inglaterra, 1700 - 1821 (\% ao ano)

\begin{tabular}{|c|c|c|c|c|}
\hline Anos & Algodão & Ferro & Construção & $\begin{array}{c}\text { Produto } \\
\text { industrial }\end{array}$ \\
\hline $\mathbf{1 7 0 0 - 1 7 6 0}$ & 1,37 & 0,60 & 0,74 & 0,71 \\
\hline $\mathbf{1 7 7 0 - 1 7 8 0}$ & 6,20 & 4,47 & 4,24 & 1,79 \\
\hline $\mathbf{1 7 8 0 - 1 7 9 0}$ & 12,76 & 3,79 & 3,22 & 1,60 \\
\hline $\mathbf{1 7 9 0 - 1 8 0 1}$ & 6,73 & 6,48 & 2,01 & 2,49 \\
\hline $\mathbf{1 8 0 1 - 1 8 1 1}$ & 4,49 & 7,75 & 2,05 & 2,70 \\
\hline $\mathbf{1 8 1 1 - 1 8 2 1}$ & 5,59 & $-0,28$ & 3,61 & 2,42 \\
\hline
\end{tabular}

Fonte: Elaborada por Freeman (2008, p. 154).

Nota: Não há citações de outras referências.

A siderurgia foi a segunda indústria de transformação da Inglaterra. O início de sua modernização foi posterior à indústria têxtil, após as guerras contra Napoleão. A siderurgia utilizava como elementos de transformação o minério de ferro e o carvão vegetal. Entretanto, as florestas da Inglaterra estavam se esgotando de forma rápida, e o país teve que procurar outra fonte de energia que substituísse o carvão vegetal. A alternativa encontrada foi a hulha (espécie de carvão mineral) (PHILIP, 1980).

A taxa de crescimento do produto industrial britânico, no período entre 1700 e 1780, variou entre meio e um por cento ao ano; mas, entre 1780 e 1870, elevou-se para mais de três por cento, uma taxa alta para a época. Isso representou uma transição para uma taxa de crescimento econômico sustentado por um longo período.

No período inicial da Revolução Industrial, os empresários perceberam a necessidade de proteger suas inovações. Naquela época, os métodos de proteção e as atitudes com relação a vários métodos dependiam do ramo de atuação industrial, assim como a facilidade e custos da imitação, mas o papel da apropriabilidade e possibilidade de exploração monopolística de inovações tinha adquirido uma importância crucial. As políticas nacionais de proteção às invenções e à inovação faziam parte das armas políticas. Aqueles que eram pegos exportando segredo dos ofícios sofriam pesadas punições. Quando Samuel Slater contrabandeou os segredos da máquina fiandeira hidráulica para os Estados Unidos, tomou o devido cuidado, não levando consigo qualquer desenho e instrução por escrito ao embarcar em um navio (FREEMAN, 2008).

Uma série de invenções e melhorias proporcionaram grandes aumentos na produtividade, cuja exploração ocorreu no novo sistema de produção britânica baseado em fábricas. Estas melhorias nas tecnologias de processo possibilitaram rápidas reduções de preços, as quais, por sua vez, deram origem à força competitiva que tornou as exportações britânicas de produtos têxteis mais baratos do que os tecidos indianos e asiáticos (FREEMAN, 2008). 
List argumentou que a Inglaterra somente começou ampliar a infraestrutura interna de transportes (canais fluviais, estrada e ferrovias) quando o setor manufatureiro se tornou forte.

\section{Comércio}

Os ingleses foram estimulados pela política real e passaram a dirigir suas próprias energias para o comércio pesqueiro. Essas energias não eram voltadas exclusivamente para o consumo interno de peixes, mas sim para uma estratégia de crescimento do país, ou seja, os ingleses queriam extrair de cada continente europeu suas habilidades nos setores específicos através do comércio. Para tanto, era fundamental o domínio do mar. A indústria da pesca promovia o desenvolvimento da indústria naval e o adestramento de navegadores, elementos fundamentais para obter uma marinha mercante (LIST, 1983).

Anteriormente, a pesca e o comércio costeiro estavam em posse dos holandeses. Em decorrência das elevadas taxas alfandegárias estabelecidas pela Inglaterra, os britânicos concentraram suas energias no comércio pesqueiro $e$, com as Leis de Navegação $0^{50}$, garantiram aos marinheiros não apenas o transporte do carvão, mas todo 0 transporte comercial marítimo. A evolução da marinha mercante levou a um aumento proporcional de seu poder naval, o que permitiu aos ingleses derrotar a frota holandesa. Logo após a promulgação das Leis de Navegação, uma guerra naval eclodiu entre a Inglaterra e a Holanda, o que levou uma suspensão quase total do comércio holandês com os países além do canal inglês, enquanto a esquadra naval holandesa no Mar do Norte e do Mar Báltico foi quase aniquilada pelos corsários ingleses (LIST, 1983).

Para List (1983), o assunto das restrições às navegações constitui em um terrível deslize aos defensores do livre comércio e sem restrições, ao ponto de emudecerem sobre esse tema. A seguinte passagem exemplifica a importância atribuída por List à navegação para o desenvolvimento das nações:

[...] uma nação pode, de um lado, assegurar vantagens incontestáveis contra nações civilizadas, as quais dessa forma serão impedidas de introduzir restrições à navegação em seu próprio benefício; de outro lado, a respectiva nação preservará assim suas próprias tripulações das indolências e as estimulará a competir com outros países na construção naval e na arte da navegação. Enquanto engajada em sua luta pela supremacia, Veneza indubitavelmente muito deve à sua política de restrição às navegações; mas no momento em que adquiriu a supremacia no comércio, nas manufaturas e na navegação, foi um gesto de insensatez manter essas restrições. Pois, devido às restrições, Veneza ficou atrás muito na competição, tanto no que respeita a construção naval quanto no que tange a navegação, a valentia de seus marujos, em relação a outras nações marítimas e comerciais que estavam progredindo. (LIST, 1983, p. 37).

$\mathrm{Na}$ passagem acima, percebe-se que, na perspectiva de List, as proteções e os subsídios devem ser temporários, ou seja, quando é atingido um grau elevado de desenvolvimento na navegação e no poder marítimo, seguramente começará uma nova era, na qual se possa revogar tais proteções e subsídios.

A Inglaterra, com sua política, aumentou seu poderio naval e por meio deste ampliou o raio de atuação manufatureira e comercial; e, finalmente, por meio dessa ampliação, aumentou novamente seu poderio marítimo e suas possessões comerciais. Os ingleses adotaram uma política de restrições comerciais quando já estavam em um elevado grau de

\footnotetext{
${ }^{50}$ As leis de navegação foram impostas pela Inglaterra determinando que as mercadorias importadas pelos países europeus só poderiam chegar a seus respectivos portos se fosse através de navios ingleses ou do país em questão. A medida resultou no completo poderio da Inglaterra sobre o comércio marítimo (LIST, p. 36).
} 
desenvolvimento e possuíam um poder e uma unidade nacional para favorecer novos recursos produtivos e desenvolver suas forças produtivas (LIST, 1983).

Conforme Chang (2004), em 1833 ocorreu uma forte redução tarifária. A grande mudança acentuou-se em 1846, quando a tarifa Corn Law foi revogada e diversas tarifas sobre bens manufaturados foram abolidas. Em 1860, o número de produtos isentos de taxas ampliou-se. No entanto, o regime de livre comércio não durou muito. Na década de 1880 , alguns fabricantes em dificuldades reivindicaram a proteção, e as tarifas voltaram no início do século XX. Deve-se notar que mesmo a política de livre comércio da Grã-Bretanha foi motivada, em parte, pelo seu desejo de promover as suas indústrias. Muitos dos advogados do comércio livre, inclusive um de seus líderes, Richard Cobden ${ }^{51}$, acreditavam que a importação livre de produtos agrícolas pela Grã-Bretanha iria desencorajar a produção industrial em países concorrentes, levando-os a se especializarem em mercadorias agrícolas.

O quadro abaixo mostra uma síntese das contribuições dos autores com o objeto e período discutido.

\section{Quadro 1 - Desenvolvimento das Forças Produtivas da Inglaterra, no período de 1750 a 1900}

\begin{tabular}{|c|c|c|c|}
\hline AUTORES & AGRICULTURA & INDÚSTRIA & COMÉRCIO \\
\hline $\begin{array}{l}\text { LIST } \\
(1983 / 86)\end{array}$ & $\begin{array}{l}\text { - lã; } \\
\text { - cereais }\end{array}$ & $\begin{array}{l}\text { - manufatura da lã, } \\
\text { algodão; } \\
\text { - artesãos; } \\
\text { - metalúrgica de ferro e } \\
\text { aço; } \\
\text {-conquistas na arte e } \\
\text { ciências }\end{array}$ & $\begin{array}{l}\text { - proteção tarifária e leis } \\
\text { de navegação; } \\
\text { - transporte marítimo, } \\
\text { fluvial e ferroviário. } \\
\text { supremacia industrial e } \\
\text { comercial }\end{array}$ \\
\hline $\begin{array}{l}\text { PHILIP } \\
(1980)\end{array}$ & $\begin{array}{l}\text { - lã; } \\
\text { - alho e trevo }\end{array}$ & $\begin{array}{l}\text { - manufatura da lã e do } \\
\text { algodão; } \\
\text { - minério de ferro e carvão } \\
\text { vegetal }\end{array}$ & $\begin{array}{l}\text { - proibição de importação } \\
\text { de tecidos indianos; } \\
\text { - desenvolvimento da } \\
\text { indústria têxtil e da } \\
\text { siderurgia; } \\
\text {-transporte ferroviário }\end{array}$ \\
\hline $\begin{array}{l}\text { HOBSBAWM } \\
\text { (1977) }\end{array}$ & $\begin{array}{l}\text { - agricultura funcional para } \\
\text { a industrialização e } \\
\text { urbanização }\end{array}$ & $\begin{array}{l}\text { - manufatura do algodão; } \\
\text { - ciência e engenharias } \\
\text { agrícolas }\end{array}$ & $\begin{array}{l}\text { - conquistar seus } \\
\text { mercados competidores; } \\
\text { - transbordamento técnico } \\
\text { e de capital para as } \\
\text { nações competidoras }\end{array}$ \\
\hline $\begin{array}{l}\text { CHANG } \\
(2004)\end{array}$ & -lã & - manufatura da lã & $\begin{array}{l}\text { - competitividade } \\
\text { internacional; } \\
\text { - estratégia de promoção } \\
\text { da indústria britânica; } \\
\text { - abertura tarifária por } \\
\text { liberalismo econômico, } \\
\text { exploração da supremacia } \\
\text { industrial e tentativa de } \\
\text { induzir especialização } \\
\text { produtiva de rivais }\end{array}$ \\
\hline $\begin{array}{l}\text { FREEMAN } \\
(2008)\end{array}$ & -lã & $\begin{array}{l}\text { - manufatura da lã e do } \\
\text { algodão; } \\
\text { - metalurgia de ferro; } \\
\text { - patentes industriais }\end{array}$ & $\begin{array}{l}\text {-importação de algodão } \\
\text { da índia e da colônia } \\
\text { norte-americana; } \\
\text { - proteção intelectual }\end{array}$ \\
\hline
\end{tabular}

Fonte: Resultados da pesquisa.

\footnotetext{
${ }^{51}$ Richard Cobden (1804-1865) foi um industrial, economista, político britânico, membro radical do partido liberal e mentor de uma associação nacional contra as Corn Laws, intitulada de Liga Anti-Lei dos Cereais.
} 


\section{Discussão}

Do estudo do caso inglês, List (1983) extrai algumas proposições. Primeiramente, para o desenvolvimento econômico ganhar corpo, o setor manufatureiro deverá operar em larga escala. Em segundo lugar, que somente em um país que desenvolveu em regime de concorrência seus recursos manufatureiros e agrícolas internos, os dispendiosos meios, instrumentos e equipamentos para o comércio cumprem adequadamente sua finalidade e compensam os custos incorridos. Por fim, o poder político e militar em uma nação é muito relevante porque tem capacidade de gerar novas forças produtivas e contribui para manter a posse da riqueza adquirida em tempos anteriores e em tempos mais recentes. O inverso deterioraria tudo o que já haveria alcançado, não somente a riqueza conquistada, mas também as forças de produção, a civilização, a liberdade e até a independência nacional, caindo nas mãos daqueles que a superaram em poder e potência. As proposições de List antecipam a perspectiva de que o poder militar e político é viabilizado pela organização industrial - capaz de gerar artefatos bélicos dissuasórios -, e pelo excedente econômico de uma produção pujante para sustentar uma capacidade estatal dedicada à proteção e articulação de estratégias de desenvolvimento.

A Inglaterra, no final do século XVIII, agregou mais poder ao que já possuía, e novas forças produtivas às forças de produção que já existiam. O país estava em posse de todas as posições estratégias importantes, dominou duas rotas comerciais para a Índia, e aumentou a produção industrial. Nesta época, ampliou sua política com a proibição das exportações do ferro, uma vez que estava escasso. A partir do século XIX, o país já fabricava mais produtos de ferro e de aço do que todas as demais nações do mundo (LIST, 1983).

Conforme List, enquanto algumas nações estavam sofrendo com os retrocessos em vários setores, a Inglaterra desenvolvia-se nesses mesmos setores.

[...] o surgimento e o progresso das cidades, progresso na agricultura, comércio, manufatura; a submissão da aristocracia na lei do país, e, portanto, uma participação intensa da nobreza, na obra da legislação, na administração do Estado e do direito, bem como nas vantagens da indústria; desenvolvimento dos recursos internos e do poder político no exterior; paz interna; influência sobre todos os países menos evoluídos; limitação dos poderes da Coroa, mais aumento, por parte da Coroa, das receitas dos reis, no tocante esplendor e a estabilidade. Em suma, um grau mais alto de bemestar, de civilização e de liberdade dentro do país, e supremacia de poder no exterior. (LIST, 1983, p. 40).

List (1983) afirmou que nenhum reino europeu se beneficiou da aristocracia como a Inglaterra. Ela contribuiu com os objetivos nacionais na medida em que atraiu para seu próprio corpo a elite da comunidade e incluiu em suas fileiras todo cidadão que merecia distinção, fosse por dotes mentais, fosse por riqueza excepcional ou por grandes empreendimentos. A nobreza recebia da Câmara dos Comuns ${ }^{52}$ novas contribuições de civismo e energia patriótica, de ciência, de erudição, de recursos intelectuais e materiais, ao mesmo tempo que a nobreza sempre restituiu ao povo uma porção da cultura e do espírito de independência.

Conforme List (1983), cada movimento político, cada guerra ocorrida no continente europeu trouxe aos ingleses grandes quantidades de capital e de novos talentos. A Inglaterra soube organizar um ambiente de liberdade, de proteção interna para os empreendimentos, de proteção legal, proporcionando o bem-estar da nação.

\footnotetext{
${ }^{52} \mathrm{~A}$ Câmara dos Comuns representava toda a sociedade inglesa que não fazia parte da elite. Seus membros eram eleitos pelo povo e representavam os interesses dos comerciantes, da pequena nobreza e do clero.
} 
$\mathrm{Na}$ perspectiva desenvolvida por List (1983), o poderio industrial e naval inglês combinado com as suas estratégias comerciais agressivas eram uma ameaça ao desenvolvimento das demais nações.

No entanto, Hobsbawm (1977) argumenta que o sucesso britânico oferecia transbordamentos que facilitaram o desenvolvimento de outros países.

Uma vez iniciada a industrialização na Grã-Bretanha, outros países podiam começar a aproveitar dos benefícios da rápida expansão econômica que a revolução industrial pioneira estimulava. Além do mais, o sucesso britânico provou o que se podia conseguir com ela, a técnica britânica podia ser imitada, o capital e a habilidade britânica podiam ser importados. A indústria têxtil saxônica, incapaz de criar seus próprios inventos, copiou os modelos ingleses, às vezes com a supervisão de mecânicos ingleses; os ingleses que tinham certo gosto pelo continente, como os Cockerill, estabeleceramse na Bélgica e em várias partes da Alemanha. Nos períodos entre 1789 e 1848 a Europa e a América foram inundadas por especialistas, máquinas a vapor, maquinaria para processamento e transformação do algodão e investimentos britânicos. Assim a Grã-Bretanha não gozava dessas vantagens. (Hobsbawm, 1977, p. 57).

De acordo com Chang (2004), com a Revolução Industrial, na segunda metade do século XVIII, a Inglaterra começou a expandir sua liderança tecnológica em relação a outros países. No entanto, mesmo assim, prosseguiu a sua política industrial de restrição a importações até meados do século XIX, altura em que a sua supremacia tecnológica já era incontestável.

O quadro abaixo compara as contribuições dos autores para ressaltar semelhanças e divergências.

\section{Quadro 2 - Semelhanças e complementos em relação à descrição da trajetória de desenvolvimento da Inglaterra}

\begin{tabular}{|c|c|c|}
\hline & & INGLATERRA \\
\hline $\begin{array}{l}\text { PONTOS } \\
\text { SEMELHANTES } \\
\text { LIST }\end{array}$ & $\mathbf{A}$ & $\begin{array}{l}\text { Os autores Philip (1980), Hobsbawm (1977), Chang (2004) e Freeman } \\
\text { (2008) convergem com List (1983; 1986) sobre o grau elevado de } \\
\text { capacidade produtiva na agricultura e indústria e crescente organização } \\
\text { comercial da Inglaterra, bem como o setor de transportes que estava } \\
\text { auxiliando o crescimento da nação. } \\
\text { Chang (2004) também relata ações inglesas para estimular os setores } \\
\text { industriais e induzir a especialização agrícola de outras nações. } \\
\text { Freeman (2008) traz muitas informações sobre o desenvolvimento } \\
\text { tecnológico e apropriação intelectual que reforçam os argumentos de List } \\
\text { (1983) sobre a importância do desenvolvimento técnico e do capital mental. }\end{array}$ \\
\hline $\begin{array}{l}\text { COMPLEMENTOS } \\
\text { AOS RELATOS } \\
\text { LIST }\end{array}$ & DE & $\begin{array}{l}\text { Enquanto List }(1983,1986) \text { afirmava que a supremacia comercial da nação } \\
\text { estava retardando as demais nações, Hobsbawm (1977) afirma que o país } \\
\text { fornecia conhecimento e capital e servia de parâmetro de imitação para o } \\
\text { crescimento das outras nações. Freeman (2008) exemplifica um caso de } \\
\text { transbordamento de conhecimento ao estrangeiro. }\end{array}$ \\
\hline
\end{tabular}

Fonte: Resultados da pesquisa. 


\section{O desenvolvimento intelectual na Alemanha}

List (2009) afirmava que a relação que tinha com a Alemanha é como "aquela das mães com as crianças aleijadas"; "quanto mais aleijadas elas são, mais elas the dedicam amor". Por ser germânico, tinha conhecimento da situação econômica e política deste território.

Pereira e Menezes (2008) ressaltam que o período entre 1818 e 1834 foi marcado por uma economia alemã não muito desenvolvida. A economia era baseada na agricultura, uma agricultura que não possuía técnicas modernas de produção, de pouca produtividade e incapaz de evitar crises de escassez. As atividades comerciais e industriais viam seu desenvolvimento entravado por divisões políticas, em que multiplicavam linhas aduaneiras e sistemas monetários, pela insuficiência dos meios de transporte, dos capitais e pela falta de organização do crédito. A sociedade aristocrática alemã, de grandes proprietários de terras, continuaria existindo e tendo poder durante muito tempo; entretanto, passaria a sentir o peso das transformações sociais sobre aquela sociedade "semifeudal".

Freeman (2004) argumenta que houve outros aspectos da herança de List que realmente foram mais importantes do que o de suas doutrinas protecionistas em moldar o clima de opiniões e de políticas na Alemanha e menos diretamente em outras nações. Refere-se às vantagens iniciais auferidas na indústria alemã e na economia alemã a partir de um sistema de educar e formar os artesãos e técnicos.

\section{O setor agrícola germânico ${ }^{53}$}

List (1983) discorre sobre a Antiga Germânia medieval, argumentando que não havia investimentos no setor agrícola, pois grande parte da terra era dedicada a pastagens e parques para a caça. A agricultura era considerada insignificante e primitiva e foi designada aos servos e as mulheres. A ocupação dos homens livres era a guerra e a caça; e esta era a origem de toda a nobreza germânica.

Os nobres alemães aderiram firmemente a este sistema durante a Idade Média, rejeitando o setor agrícola, opondo-se à manufatura e ignorando uma futura prosperidade desses setores. Os nobres alemães conservaram essa cultura por muitos anos, preservando suas propriedades para a caça, ajardinamento e reflorestamento (LIST, 1983).

Conforme List (1983), a agricultura alemã permaneceu por muito tempo em uma situação estagnada, embora não se possa ignorar a influência das cidades e dos mosteiros sobre as regiões localizadas nas proximidades agrícolas. As cidades prosperavam pelas necessidades locais e pelo transporte externo. Os mosteiros, nesse contexto, se destacavam porque os monges, ao ficarem muito tempo isolados, contribuíram para o progresso intelectual, desenvolvendo novas técnicas científicas para suprir suas necessidades mediante a produção manufatureira.

Hobsbawm (1977) ressalta que, em 1879, as burocracias de inúmeros pequenos principados, que eram pouco mais que grandes propriedades, administravam os anseios das altezas com os impostos cobrados do campesinato. A cidade provinciana de fins do século XVIII podia ser uma próspera comunidade em expansão e essa prosperidade advinha do campo. Entretanto, no período entre 1815 e 1830 a agricultura do país definhava. Na década de 1830, na Alemanha, as reclamações vinham sobre o crescente empobrecimento e a escassez de alimentos. O ponto crucial do problema agrário era a relação entre os que cultivavam a terra e os que a possuíam, os que produziam a riqueza e os que a acumulavam.

Tilly (1978) discorre que, nas décadas de 1806-1816, houve maior utilização dos fatores de produção terra, trabalho e capital pelo setor agrícola. Como resultado, ocorreu

\footnotetext{
${ }^{53}$ Antes da Unificação de 1870, o território germânico estava fragmentando em 39 estados que formavam a Confederação Germânica.
} 
aumento substancial do nível global da produção. Há alguma evidência de "superprodução" durante o início de 1820. Porém, no horizonte de 1820-1850, os termos de troca tenderam a favorecer a agricultura - uma das razões para a sua expansão. E destaca que, nos anos subsequentes, o setor agrícola estava servindo de incentivo para a produção industrial no país.

However, much more substantial increases in agricultural productivity in Prussia appear to have taken place in the 1850s and 1860s, accompanied also by a large increase in total production. They took place, that is, during the "take-off", when, as we know, the non-agricultural sectors were already growing substantially. The conclusion of this review of agriculture's role in early Prussian industrialization is therefore that agriculture was probably not an important "leading sector" (I say "probably" because more information is necessary before this issue can be settled). However, it is true that agriculture could play a significant permissive role. (TILLY, 1978, p. 385).

De acordo com Philip (1980), até o início do século XIX, a Alemanha, dividida por uma multiplicidade de pequenos principados, manteve-se essencialmente rural. Conforme 0 autor, o país distinguia-se em duas regiões. A estrutura de Oeste seguia com pequenas propriedades campesinas ainda submetidas aos resquícios feudais. A estrutura de Leste era, pelo contrário, a terra conquistada por uma aristocracia militar e pertencia aos senhores e aos camponeses que estavam reduzidos à servidão. Entre as duas, estava Berlim, uma cidade de soldados que, com suas famílias, representavam mais de um terço da população.

Desde o período medieval até a primeira metade do século XIX, a agricultura germânica aumentou lentamente a sua oferta, limitada pela estrutura social feudal rural.

\section{O setor industrial}

Um grande sistema da indústria nascente, capaz de fornecer produtos para o comércio de exportação, só poderia se desenvolver por uma extensa criação de ovelhas e uma ampla cultura de linho, sendo que o início da primeira onda de industrialização deu-se com a indústria têxtil (LIST, 1983).

List (1983) descreve que a economia da Alemanha não estava somente atrasada no setor agrícola, como também na legislação, na administração do Estado e na administração da Justiça, no setor industrial, bem como em todo o comércio em larga escala, com uma falta de unidade e de força na coesão nacional. List $(1983,1986)$ assinala que, em meio a um quadro social e econômico conturbado, os alemães preservaram uma base institucional caracterizada pela ênfase em valores relacionados ao trabalho, à ordem, à parcimônia, à modernidade e a outras características que viabilizaram o desenvolvimento das atividades produtivas e concernentes aos negócios na sociedade alemã.

Para List $(1983,1846)$, os fundamentos de restabelecimento da nacionalidade alemã foram colocados pelos próprios governos pela promoção do desenvolvimento intelectual. List acreditava que o desenvolvimento intelectual era uma peculiaridade positiva para o desenvolvimento alemão, ligado a investimentos em instrução, ciência e artes, da moralidade e dos objetivos do bem público.

As primeiras medidas governamentais para promover a manufatura alemã foram introduzidas pela Áustria e pela Prússia no século XVIII. A Áustria havia sofrido muito com a expulsão dos protestantes, pois eram os cidadãos mais devotos ao trabalho. Depois, em consequências das tarifas protecionistas, da criação de ovelhas, da abertura de estradas e outras melhorias, a indústria acusou notáveis progressos. O sistema alfandegário protecionista foi um mecanismo para o progresso na indústria e o crescimento da agricultura, além de uma ascensão no progresso intelectual e da cultura mental (LIST, 1983). têxtil.

Tilly (1978) argumenta que a produção industrial germânica se baseava no setor 
[...] on capital shortage in Germany in the first half of the nineteenth century concentrated on the adequacy of finance but at the same suggested quite strongly that industrial investment was of minor quantitative importance for this question. His most striking example showed Germany's largest industrial sector - the textile industries - to be absorbing only a small fraction of presumed savings during this period. In a later work treating all textile industries in the states of the Zollverein in 1846, it was estimated an increase in capital stock. (TILLY, 1978, p. 418.).

Apesar dos obstáculos estabelecidos por sistemas monetários e alfandegários internos à comunidade germânica, as manufaturas fizeram seu aparecimento a partir de 1830. Sendo que, no período de 1825 a 1850, ocorreu um expressivo aumento na produção do carvão, do ferro fundido e do cavalo-vapor utilizados. Em 1827, em virtude do aumento nas fábricas de fiação, cresceu a produção de têxteis. Até 1860 , o setor industrial conservou essencialmente o regime do artesanato doméstico disperso pela província (PHILIP, 1980).

Em 1835, foram introduzidas as primeiras ferrovias, consideradas uma das maiores inovações na Alemanha. As estradas de ferro ligavam os países e os continentes, com suas obras engenharia, estações e pontes desenvolvendo um conjunto de construções que desvaneceram do provincianismo (HOBSBAWM, 1977).

Conforme Freeman (2008), a tradição da gestão alemã era pesadamente influenciada por profissionais engenheiros, que tiveram status elevado e altas recompensas. A introdução de novas tecnologias foi uma das características que diferenciou o sistema alemão da indústria britânica, além de uma alta qualidade no lado técnico.

A importância desse caminho de longo prazo foi de algum modo confinado à indústria. Também foi extremamente importante a atuação do governo, por exemplo, no financiamento de investigação e educação, bem como em medidas para promover indústrias estratégicas e instituições financeiras. A transferência de tecnologia promovida e coordenada pelo Estado prussiano foi altamente bem sucedida, as indústrias de máquinas operatrizes e a construção mecânica da Alemanha passaram a ser capazes de projetar e fabricar máquinas necessárias para fazer locomotivas a vapor no país nas décadas de 1840 e 1850, o que criou condições para ultrapassar a Grã Bretanha (FREEMAN, 2008).

Freeman (2004) salienta que uma importante contribuição do país no século XIX foi a descoberta do método de invenção em laboratório de pesquisa profissional. As universidades alemãs foram as primeiras a institucionalizar um sistema de laboratórios de ciências e formação de pós-graduação através de pesquisas de laboratório, que mais tarde se tornou característica do ensino das ciências em geral. Isto foi especialmente importante para a nascente indústria química alemã. Para Freeman, foi a indústria alemã de anilinas sintéticas que primeiro percebeu a lucratividade de se estabelecerem as atividades de pesquisa e desenvolvimento de novos produtos e processos químicos em uma base mais regular, sistemática e profissional.

A partir de 1840, com o crescimento do setor privado, diminuiu a interferência dos Estados germânicos no desenvolvimento industrial. Entretanto, isso não significou recuo, e sim a transição de um papel diretivo para um mais orientador. O Estado direcionou os investimentos para as bolsas de estudos, aos subsídios para empresários competentes e à organização de máquinas e processos industriais novos (TRIBILCOCK, 1981, apud CHANG, 2004).

\section{O setor comercial}

Conforme List (1983), com as devastações da Guerra dos Trinta Anos ${ }^{54}$ a indústria da Prússia sofreu mais do que qualquer outro país. A indústria de tecido que era instalada

\footnotetext{
${ }^{54}$ A Guerra dos Trinta Anos (1618-1648) repercutia conflitos religiosos entre católicos e protestantes e devastou muitas cidades da comunidade germânica. A Holanda e a Suíça separam-se do Império Germânico (união de
} 
no território de Brandemburgo foi praticamente extinta. As maiorias dos trabalhadores de tecidos haviam migrado para Saxônia, enquanto os artigos importados dos ingleses impediram qualquer concorrência. Por outro lado, a anulação do Edito de Nantes ${ }^{55}$ foi vantajosa, pois um grande número de fugitivos dirigiu-se para a Prússia, fomentando a agricultura do país, estabelecendo um grande número de indústrias, e dedicando-se à ciência e à arte. Tarifas alfandegárias protegeram a produção agrícola.

Por volta de 1820, a Alemanha inteira estava em uma só Associação Alfandegária (Zollverein), a qual aboliu alfândegas entre um Estado germânico e outro, estabelecendo também tarifas uniformes e unitárias comuns em relação aos produtos estrangeiros, sendo que a renda proveniente da cobrança dessas tarifas aduaneiras era distribuída entre diversos Estados alemães, de acordo com a população de cada um. Em decorrência dessa unificação aduaneira, a indústria, o comércio e a agricultura dos Estados alemães integrantes dessa Associação registraram avanços enormes (LIST, 1983).

Philip (1980) aborda que, desde 1810, os intelectuais e universitários e uma pequena parcela de classe média reclamavam por uma Constituição. Com a depressão nos anos 1846-1847, veio o apoio provisório das massas artesanais e rurais, pois os preços do trigo e das batatas aumentavam em consequência das más colheitas e a Alemanha via-se forçada a importar cereais; a indústria têxtil estava em crise, provocando desemprego aos assalariados e acelerando a ruína dos artesões. Depois de tamanha recessão, a Prússia começava a impor-se pouco a pouco a todo o país, conquistando as massas através de uma política intervencionista que visava à expansão econômica e à proteção social. A partir de 1848, o Zollverein muitos Estados germânicos a fim de proteger seus mercados. Nesse período, multiplicavam-se as indústrias, as quais eram alimentadas pela transformação dos transportes.

\section{Quadro 3 - O desenvolvimento das forças produtivas da Alemanha.}

\begin{tabular}{|c|c|c|c|}
\hline AUTORES & AGRICULTURA & INDÚSTRIA & COMÉRCIO \\
\hline $\begin{array}{l}\text { LIST } \\
(1983 / 86)\end{array}$ & $\begin{array}{l}\text { - lã; } \\
\text { - cereais }\end{array}$ & $\begin{array}{l}\text { - manufatura da lã, seda, } \\
\text { joias, chapéus, porcelana; } \\
\text { - progresso intelectual e } \\
\text { cultura mental; } \\
\text { - incentivo aos } \\
\text { transportes. }\end{array}$ & $\begin{array}{l}\text { - associação alfandegária; } \\
\text { (Zollverein). }\end{array}$ \\
\hline $\begin{array}{l}\text { PHILIP } \\
(1980)\end{array}$ & $\begin{array}{l}\text {-lã; } \\
\text {-cereais }\end{array}$ & $\begin{array}{l}\text { - fábricas de fiação; } \\
\text { - carvão e ferro fundido; }\end{array}$ & --Zollverein \\
\hline $\begin{array}{l}\text { HOBSBAWM } \\
\text { (1977) }\end{array}$ & - cereais & - estradas de ferro & - \\
\hline $\begin{array}{l}\text { TILLY } \\
(1978)\end{array}$ & $\begin{array}{l}\text {-lã; } \\
\text { - grãos; } \\
\text { - superprodução agrícola. }\end{array}$ & - setor têxtil. & - \\
\hline $\begin{array}{l}\text { CHANG } \\
(2004)\end{array}$ & - & $\begin{array}{l}\text {-inovação no setor de } \\
\text { máquinas; } \\
\text { - ferro fundido }\end{array}$ & $\begin{array}{l}\text { - Zollverein; } \\
\text { - tarifas alfandegárias de } \\
\text { importação relativamente } \\
\text { brandas }\end{array}$ \\
\hline $\begin{array}{l}\text { FREEMAN } \\
(2008)\end{array}$ & - & $\begin{array}{l}\text { - formar artesãos, técnicos } \\
\text { e tecnólogos; } \\
\text {-indústria química }\end{array}$ & \\
\hline
\end{tabular}

Fonte: Resultados da pesquisa.

territórios na Europa Central medieval), enquanto as províncias mais leais ao império foram conquistadas pela França (LIST, 1983, p. 61).

55 O Edito de Nantes de 1598 suspendeu a perseguição religiosa aos huguenotes calvinistas na França. Foi revogado em 1685, fato que levou a uma dispersão deste grupo social e de suas capacidades produtivas por outros países. 


\section{Discussão}

Conforme List (1983), foi propício abolir as tarifas aduaneiras internas que separavam os alemães uns dos outros. Todavia, a nação teria auferido pouca vantagem disso se sua indústria nacional permanecesse exposta à concorrência externa. $O$ milagre ocorreu através das taxas Zollverein que protegeram os artigos manufaturados de uso comum. List argumenta que o Zollverein impôs taxas protecionistas de $20 \%$ até $60 \%$ em relação aos manufaturados de uso comum.

O setor agrícola também se beneficiou das altas taxas, em decorrência do aumento pela demanda por produtos agrícolas. Com a elevação das taxas, era notório um crescimento da manufatura nacional, uma elevação no valor das terras com um aumento de 50 a $100 \%$, uma ascensão nos salários, e ainda o aperfeiçoamento nos meios de transporte ou a elaboração de projetos para isso (LIST, 1983).

Em contrapartida, Chang (2004) ressalta que a Alemanha geralmente é conhecida como berço da proteção às indústrias nascentes, em aspectos tanto intelectuais quanto políticos. Contudo, descrevendo historicamente, a verdade é que a proteção tarifária teve, no desenvolvimento econômico alemão, um papel bem menos importante do que no britânico ou no norte-americano.

Chang (2004) acrescenta que, na Prússia, a proteção tarifária na indústria foi moderada até 1834, quando da criação da união aduaneira, o Zollverein, sob sua liderança, que depois se estendeu à indústria alemã em geral. Chang (2004 apud TREBILCOCK, 1981) ressalta que as tarifas Zollverein não satisfaziam para dar proteção efetiva à indústria nascente, pois os fabricantes de ferro permaneceram sem tarifas até 1844 e seguiram carecendo de proteção eficaz até depois disso. O Estado prussiano resistia constantemente à pressão política dos outros Estados-membros da Zollverein, que reivindicavam tarifas mais elevadas. A tarifa Zollverein encerrou-se no final da década de 1870, em consequência do acordo bilateral de livre comércio com a França, em 1862, e da redução da alíquota de aço, em 1870.

\section{Tabela 2 - Taxa tarifária dos produtos manufaturados ${ }^{1}$ (em porcentagem de valor) ${ }^{2}$}

\begin{tabular}{|c|c|c|}
\hline Nações & $\mathbf{1 8 2 0}$ & $\mathbf{1 8 7 5}$ \\
\hline Reino Unido & $44-55$ & 0 \\
\hline Alemanha & $8-12$ & $4-6$ \\
\hline EUA & $35-45$ & $40-50$ \\
\hline
\end{tabular}

Fonte: Bairoch (1993) apud Chang (2004).

Notas: Elaborado por Chang (2004, p. 36).

Médias ponderadas oferecidas por Bairoch.

Nota-se, a partir da Tabela 2, que a taxa de proteção da Alemanha sobre os produtos manufaturados era muito pequena, frente a do Reino Unido nos anos de 1820 e dos Estados Unidos em 1820 e 1875. 


\section{Quadro 4 - Semelhanças e complementos em relação à descrição da trajetória de desenvolvimento da Alemanha}

\begin{tabular}{l|l}
\hline & ALEMANHA \\
\hline $\begin{array}{l}\text { PONTOS } \\
\text { SEMELHANTES A } \\
\text { LIST }\end{array}$ & $\begin{array}{l}\text { Os autores Philip (1980), Hobsbawm (1977), Tilly (1978), Chang (2004) e } \\
\text { Freeman (2008) convergem com List sobre o desenvolvimento agrícola e } \\
\text { industrial da nação. Um marco importante foi Associação Alfandegária } \\
\text { entre os Estados e juntamente com Estados economicamente atuantes. } \\
\text { A agricultura, até a primeira metade do século XIX, aumentou lentamente a } \\
\text { sua oferta, limitada pela estrutura social feudal rural. }\end{array}$ \\
$\begin{array}{l}\text { COMPLEMENTOS } \\
\text { AOS RELATOS DE } \\
\text { LIST }\end{array}$ & $\begin{array}{l}\text { Chang (2004) destaca que a proteção tarifária contra terceiros do } \\
\text { Zist deu a este fator. Com esta releitura, a capacidade de coordenação } \\
\text { política e econômica do Estado, a organização do aprendizado técnico, } \\
\text { bem como a livre circulação comercial interna ao bloco ganham relevo } \\
\text { como elementos de desenvolvimento. }\end{array}$
\end{tabular}

Fonte: Resultados da Pesquisa.

\section{As tarifas protecionistas dos Estados Unidos da América}

List $(1983 ; 2009)$ apresenta os esforços dos norte-americanos para a organização produtiva daquela nação em meados do século XIX. Os Estados Unidos estavam em estado intermediário de desenvolvimento, aquém do poder econômico e político da Inglaterra. $O$ país passou por várias dificuldades, desde a sua Guerra por Independência até a Guerra Civil. List esteve exilado nos Estados Unidos entre 1825-1830, oportunidade na qual teve reiterados contatos com o pensamento de Alexander Hamilton.

Hamilton (2009) compara a agricultura e a manufatura, explicitando o comportamento desses setores e qual deles seria mais eficiente nos Estados Unidos. Na agricultura havia riscos advindos do clima, bem como da fertilidade da terra, com um considerável grau de imprevisão na forma de cultivá-la. $\mathrm{Na}$ manufatura, o artesão poderia obter grande produtividade na medida em que os demais trabalhadores se dedicassem a tarefas complementares na mesma atividade e ocorresse o desenvolvimento de técnicas uniformes de produção. E, dessa mesma forma, poder-se-ia ter como certo que as manufaturas ampliariam a produtividade humana. $O$ trabalho empregado nas manufaturas era mais constante, uniforme e engenhoso do que o empregado na agricultura, e também mais produtivo.

\section{A identidade do setor agrícola e industrial nos Estados Unidos}

Hamilton (2009) ressalta que os Estados Unidos não podiam comercializar com a Europa em condições de igualdade. A falta de reciprocidade os tornava vítimas do sistema europeu que forçava o país a restringir seus anseios à agricultura e a abastecer-se das manufaturas importadas. A constante e crescente necessidade americana de bens europeus e a parcial e ocasional demanda dos seus, em troca, os expunha a uma situação de empobrecimento, em lugar da riqueza a qual a vantagens naturais e políticas lhes dariam direito a aspirar. Consequentemente, competiria aos norte-americanos esforçarem-se para ficarem menos dependentes de combinações políticas do exterior.

Conforme Hamilton (2009), a agricultura, em um primeiro momento, seria mais promissora, devido às imensas extensões de território fértil, virgem e inabitado, fatores que 
tornavam vantajoso o emprego e o capital convertido em fazendas produtivas. O problema que ele aponta é que a concorrência estrangeira e a "força do hábito" impediriam que novas indústrias, que em breve poderiam ser competitivas internacionalmente - as indústrias nascentes -, se desenvolvessem no país, a menos que uma ajuda governamental compensasse os prejuízos iniciais.

Freeman (2008) argumenta que os primeiros imigrantes foram coagidos, por uma questão de sobrevivência, a aprender através da prática as técnicas agrícolas adequadas ao continente norte-americano, e desde cedo surgiu uma pesquisa agrícola com o forte apoio público. Enquanto na Europa feudal as instituições retardavam tanto o desenvolvimento agrícola como o industrial, os Estados Unidos nunca tiveram qualquer instituição feudal, seja na agricultura ou em qualquer outra parte da economia.

De acordo com List (1983), por volta dos anos de 1750, os Estados Unidos eram abastecidos pela Inglaterra tanto no comércio como na indústria. O monopólio dos ingleses no setor industrial foi uma das principais causas da Revolução Americana, as taxas alfandegárias sobre o chá apenas proporcionaram uma oportunidade para a sua eclosão.

Os norte-americanos libertaram-se das restrições impostas pela Inglaterra e estavam em posse de todos os recursos materiais e intelectuais para a necessidade da indústria. Após a independência, a nação dependia de seus próprios recursos para se desenvolver.

Durante a Guerra de Independência, os Estados livres da América do Norte receberam um poderoso estímulo nas manufaturas e na agricultura, pois, mesmo com a devastação da guerra, o valor das terras e os salários elevaram-se nesses estados. No entanto, a constituição defeituosa dos Estados livres introduziu um sistema comercial falho, que impunha insuficiente taxação às importações; e, consequentemente, os ingleses entraram novamente no mercado americano, preenchendo a demanda interna do país não atendida pelas manufaturas locais. A prosperidade que tinha surgido durante a guerra desapareceu muito mais rapidamente do que tinha crescido (LIST, 1983).

List (1983) defende que os americanos haviam aprendido, com a experiência, que não se pode atingir estágio elevado de prosperidade se não estiver assegurada a troca de produtos agrícolas por artigos manufaturados; que, quando um agricultor vive na América e um manufator na Inglaterra, não é raro que o intercâmbio seja interrompido por guerras, crises comerciais ou tarifas estrangeiras ${ }^{56}$; e, por conseguinte, para alcançar o bem-estar nacional, o agricultor deve estar bem próximo do manufaturador.

Foi através das costas do Atlântico que os colonizadores europeus e a civilização europeia deram início ao progresso. Na costa leste, subsequentemente, nasceram os estados populosos e ricos, nos quais se estruturou a pesca marítima e o comércio costeiro que, por sua vez, levou a um aumento da força naval. Era através desses estados da costa atlântica que se processava o comércio exterior do país e através deles que o país recebia a população excedente, o material, o capital e as forças intelectuais da Europa (LIST, 1983).

Philip (1980) aborda que eles passaram por várias dificuldades para conquistar sua independência. Os colonos tinham emigrado para América por estarem fartos com 0 governo autoritário inglês. Foi a partir desse período que o setor agricultura se caracterizou pela valorização de novas terras. Os adiantamentos fornecidos pelos camponeses financiaram algumas das primeiras indústrias, e foi a partir da procura por produtos por parte dos camponeses que se constituíram os mercados internos da indústria nascente. A industrialização foi introduzida por um sistema industrial doméstico, destacando-se os artesãos e os pequenos industriais do ramo têxtil.

Conforme Hobsbawm (1977), na década de 1790 as plantações escravagistas do sul dos Estados Unidos foram aumentadas e mantidas pelas demandas das fábricas de Lancashire (noroeste de Inglaterra), às quais forneciam a grande parte da sua produção de algodão bruto. Os Estados Unidos ressentiam-se da falta pura e simples de uma colonização e de meios de transporte para explorar seu imenso território e seus recursos aparentemente ilimitados. O mero processo de expansão interna foi bastante para manter

\footnotetext{
${ }^{56}$ As exportações americanas foram afetadas pelas restrições das Corn Laws inglesas desde 1815.
} 
sua economia em um crescimento quase ilimitado, mediante os colonizadores, missionários e comerciantes americanos que migravam em direção à costa do Pacífico.

De acordo com Freeman (2008), até a primeira metade do século XIX, apesar de uma rica dotação de recursos naturais e muitas instituições favoráveis, o crescimento dos Estados Unidos fora retardado pela falta de adequada infraestrutura de transportes para o devido aproveitamento da dotação do tamanho do país. O advento das ferrovias capacitou os empresários norte-americanos a avançarem muito mais rapidamente do que o resto do mundo. Inicialmente, o país importava boa parte da tecnologia da Europa, mas, desde o começo, os inventores norte-americanos foram modificando e reformulando essas tecnologias para adequá-las às circunstâncias dos EUA.

A partir 1815, desenvolveu-se a navegação marítima costeira. Em 1850, graças aos barcos a vapor, os percursos de navios tiveram o seu tempo reduzido nas rotas dos Grandes Lagos. Em 1840, teve início a construção de linhas de ferro, predominantemente no norte e na região centro-oeste. Ocorreu o lançamento das primeiras companhias de caminhos de ferro; para encorajar esse investimento, o Estado fez concessões de terra às companhias na extensão de vinte quilômetros de cada lado da via férrea. A terra era revendida e se tornava objeto de especulação, sendo comprada pelos grandes proprietários. Com o decorrer do tempo foram acrescentadas grandes vias férreas transcontinentais (PHILIP, 1980).

Hobsbawm (1977) ressalta que havia um grande entrave que atrapalhava a conversão dos Estados Unidos em uma potência econômica mundial: o conflito entre o norte agrícola e industrial e o sul semicolonial. Enquanto o norte se beneficiava absorvendo capital, mão de obra e habilidades da Europa - e notadamente da Grã-Bretanha - como uma economia independente, o sul absorvia pouco destes recursos e era uma economia tipicamente dependente da Grã-Bretanha.

O norte e o sul competiam pelos territórios do oeste. O sul queria desenvolver novas plantações agrícolas mediante a utilização da mão de obra escrava e o norte queria para lá vender máquinas agrícolas e lá constituir os matadouros de grande porte. O futuro da economia americana só seria decidido na Guerra Civil de 1861-1865, que foi, de fato, a unificação da América através do capitalismo do norte (HOBSBAWM, 1977).

De acordo com Chang (2004), os Estados do Sul ainda estavam interessados em importar bens manufaturados da Inglaterra, pois eram de melhor qualidade e não haviam implantado indústrias em seu território. Por outro lado, os Estados do Norte e do Oeste estavam começando a proteger suas manufaturas de pouco valor agregado, como lã, linho e bebidas alcoólicas. Isso causou uma tensão entre os Estados do Norte e do Sul.

Já na primeira metade do século XIX, o desenvolvimento de uma forma especificamente norte-americana de poupar mão de obra, ou seja, a trajetória tecnológica capital intensiva para produção mecanizada e padronizada, permitiu que a indústria do país viesse a ultrapassar os britânicos por volta de 1850. À medida que o século avançava, as técnicas de engenharia de produção em larga escala e as altas taxas de produção e de circulação se tornaram mais plenamente exploradas e mais amplamente difundidas. Os administradores de empresas tornaram-se mais experientes na organização e no financiamento de grandes firmas voltadas para a criação e exploração de mercados massificados (FREEMAN, 2008).

Para Freeman (2008), no final do século XIX os Estados Unidos obtiveram um significativo aumento na oferta de ferro e aço em relação à produção do início do século. Houve significativo desenvolvimento na engenharia pesada, na maquinaria e nos equipamentos e nos armamentos de aço. 


\section{O comércio norte-americano}

Em 1789, no governo de James Madison ${ }^{57}$, foi inserida a primeira lei aduaneira norteamericana. Apesar de serem impostas taxas razoáveis à importação dos produtos manufaturados, os efeitos foram positivos, auxiliando o crescimento da nação nos setores de manufatura, comércio e agricultura. Entretanto, com o passar do tempo essa proteção demonstrou-se inadequada, porque a magnitude das taxas era facilmente inutilizada pelos manufatores ingleses, que contavam com a vantagem de seus métodos e processos de produção mais elaborados. O Congresso elevou as taxas de importação sobre os produtos manufaturados a 15\%, mas isso só ocorreu em 1804, quando foi obrigado, em face da ausência de receitas alfandegárias, a procurar novas fontes de receitas. Os norteamericanos estavam esgotando seus argumentos em favor do protecionismo, enquanto os ingleses continuavam a defender o livre comércio (LIST, 1983).

Conforme List (1983), com a proteção da tarifa de 1804, as manufaturas norteamericanas conseguiram manter-se. No entanto, o setor industrial sucumbiria novamente à concorrência inglesa se não fosse pela ajuda do embargo e declaração de Guerra de $1812^{58}$. Em consequência desses eventos, assim como na época da Guerra da Independência, as fábricas americanas receberam um impulso tão extraordinário, a ponto de não somente suprirem a demanda interna como começarem a exportar seus produtos. A partir de 1815 a produção de lã e algodão conectou-se a um crescimento elevado na produção manufatureira; esta ligação criou inúmeros empregos. Com o crescimento do setor manufatureiro, ocorreu uma rápida elevação de todos os preços.

List (1983) ressalta que em 1828 as tarifas de importação dos Estados Unidos voltaram a ser majoradas e o setor industrial cresceu de forma inacreditável, principalmente na manufatura do algodão e da lã. A miséria, a brutalidade e o crime eram desconhecidos entre a população manufatureira dessa nação. Pelo contrário, encontrava-se a mais rigorosa moralidade e decência por parte dos trabalhadores na manufatura.

Nenhuma nação teria sido tão mal interpretada e julgada em seu destino e quanto a sua economia nacional quanto os Estados Unidos. Os próprios teóricos Smith e Say afirmavam que o país estava predestinado à produção agrícola. Essa percepção desfazia as aspirações de algumas dúzias de repúblicas novas. O que os teóricos acima não previam é que o país tomaria uma decisão de bem-estar da nação contrária ao livre comércio (LIST, 1983).

A economia americana era muito diferente da economia inglesa. A economia nacional inglesa tinha por prioridade produzir manufaturas para todo o mundo, monopolizar todo o poder manufatureiro, mesmo às expensas das vidas de cidadãos, para manter o mundo e suas colônias em um estado de submissão pela administração política, bem como pela superioridade de seu capital, de suas capacidades e sua Marinha de Guerra. O escopo da economia política americana vislumbrava um desenvolvimento econômico no mercado interno, pela combinação do crescimento da agricultura, da indústria e da infraestrutura e, adicionalmente, a segurança deste desenvolvimento doméstico com tarifas protecionistas naturalmente direcionadas contra os ingleses (LIST, 2009).

Em 1832, aprovou-se uma nova lei alfandegária beneficiando especificamente o ferro e o setor têxtil com elevadas taxas de proteção de $40 \%$ do valor das mercadorias. Os períodos seguintes entre 1846 e 1861 foram rotulados como "protecionismo moderado", isso porque, a lei de 1846 trouxe uma redução no protecionismo, ainda que o imposto médio ad valorem sobre as 51 categorias mais importantes de bens importados continuasse sendo $27 \%$. Houve uma redução em 1857 , dessa vez viabilizada pela aliança dos democratas com os fabricantes de roupas, que queriam incluir a lã crua na lista livre, e com interesses das ferrovias, que queriam o ferro importado isento de tarifas. Todavia, esse protecionismo foi considerado moderado apenas nos padrões históricos dos Estados Unidos (CHANG, 2004).

\footnotetext{
57 Presidente dos Estados Unidos (1809-1817).

${ }^{58}$ Estados Unidos declaram guerra à Inglaterra.
} 
Comparando-se com as taxas praticadas por Reino Unido e Alemanha, informadas na Tabela 2, revela-se um protecionismo elevado.

No início do século XIX, os Estados Unidos não só foram os mais fortes defensores das políticas protecionistas, como também a sede intelectual desse pensamento. Na época, os intelectuais norte-americanos tinham convicção de que um país novo exigia condições econômicas diferentes do Velho Mundo (CHANG, 2004).

O Quadro 5 resume as principais afirmações dos autores consultados.

\section{Quadro 5-O desenvolvimento das forças produtivas dos Estados Unidos}

\begin{tabular}{|c|c|c|c|c|}
\hline AUTORES & ANO & AGRICULTURA & INDÚSTRIA & COMÉRCIO \\
\hline LIST & $1983 / 86$ & $\begin{array}{l}\text {-lã; } \\
\text { - algodão; } \\
\text { - terras não } \\
\text { cultivadas em seu } \\
\text { território fértil }\end{array}$ & $\begin{array}{l}\text { - manufatura da lã } \\
\text { e do algodão }\end{array}$ & $\begin{array}{l}\text { - elevadas taxas } \\
\text { alfandegárias; } \\
\text { - administração } \\
\text { por um estado } \\
\text { atuante }\end{array}$ \\
\hline HAMILTON & 2009 & $\begin{array}{l}\text { - lã; } \\
\text { - algodão; } \\
\text { - território fértil, } \\
\text { virgem e inabitado }\end{array}$ & $\begin{array}{l}\text { - manufatura da lã } \\
\text { e do algodão }\end{array}$ & $\begin{array}{l}\text { - forte proteção, } \\
\text { com um estado } \\
\text { atuante }\end{array}$ \\
\hline PHILIP & 1980 & $\begin{array}{l}\text { - valorização em } \\
\text { novas terras. }\end{array}$ & $\begin{array}{l}\text { - ramos têxteis; } \\
\text { - caminhos de } \\
\text { ferro; } \\
\text { - indústria } \\
\text { química; } \\
\text { - vias férreas } \\
\text { transcontinentais }\end{array}$ & $\begin{array}{l}\text { - medidas } \\
\text { protecionistas }\end{array}$ \\
\hline HOBSBAWM & 1977 & - algodão bruto & $\begin{array}{l}\text {-ferrovia } \\
\text { transcontinental }\end{array}$ & $\begin{array}{l}\text { - fortes medidas } \\
\text { protecionistas }\end{array}$ \\
\hline CHANG & 2004 & - & $\begin{array}{l}\text { - manufatura de } \\
\text { produtos têxteis e } \\
\text { ferro }\end{array}$ & $\begin{array}{l}\text { - fortes medidas } \\
\text { protecionistas }\end{array}$ \\
\hline FREEMAN & 2008 & $\begin{array}{l}\text { - dotação de } \\
\text { recursos naturais; } \\
\text { - pesquisa na área } \\
\text { agrícola }\end{array}$ & $\begin{array}{l}\text { - ferrovias; } \\
\text { - manufatura de } \\
\text { ferro e aço; } \\
\text { - intensificação de } \\
\text { capital } \\
\text { gerenciamento de } \\
\text { fluxos de produção } \\
\text { em larga escala }\end{array}$ & - \\
\hline
\end{tabular}

Fonte: Resultado da Pesquisa.

\section{Discussão}

Conforme List (1983), após o Tratado de Gand ${ }^{59}$, o Congresso decretou que as taxas alfandegárias fossem aumentadas de 100\%; e, durante o período de vigência desta política, o país continuou a prosperar. Entretanto, o próprio Congresso, coagido pelos poderosos interesses privados que se opunham aos manufatores nacionais, e convencido pelos argumentos dos teóricos da economia, resolveu, no ano de 1816, fazer uma considerável redução nas taxas aduaneiras, causando os mesmos efeitos de 1786-1789, ou seja, a ruína das manufaturas, a falta de mercado para a produção nacional, a queda no valor da propriedade e a calamidade geral entre os proprietários de terras.

\footnotetext{
${ }^{59}$ Ao final da Guerra de 1812 (1812-1814) fixava a fronteira norte com o Canadá, domínio inglês.
} 
O protecionismo apenas traz benefício para a prosperidade na medida em que corresponda ao grau de desenvolvimento industrial da respectiva nação; o protecionismo exagerado é nocivo; as nações só podem chegar a possuir uma grande forma manufatureira gradualmente (LIST, 1983).

Na perspectiva de Chang (2004), a indústria americana no século XIX não precisava de toda a proteção de que dispôs, e muitas tarifas perduraram mais do que foram úteis. Também cabe destacar o papel desempenhado pelo governo no desenvolvimento infraestrutural e no apoio em pesquisa e desenvolvimento.

Para Freeman (2008), outro aspecto que caracterizava a economia política norteamericana eram os esforços dos empresários para o aumento de escala dos processos de produção e para a inovação de maquinários e de sistemas produtivos projetados para servir mercados muito grandes. A dimensão da infraestrutura de transportes e comunicação (ferrovia e telégrafos) que, em meados do século XIX, permitiram aos Estados Unidos tirar proveito de sua ampla dotação de recursos naturais e seu vasto território para obtenção de suas economias de escala não foi encontrada em qualquer outro lugar do mundo.

\section{Quadro 6 - Semelhanças e complementos em relação à descrição da trajetória de desenvolvimento dos Estados Unidos da América}

\begin{tabular}{l|l}
\hline & ESTADOS UNIDOS \\
\hline $\begin{array}{l}\text { PONTOS } \\
\text { SEMELHANTES A } \\
\text { LIST }\end{array}$ & $\begin{array}{l}\text { Os autores Philip (1980), Hobsbawm (1977), Chang (2004) e Freeman } \\
\text { (2008) convergem com List quanto aos estágios de desenvolvimento da } \\
\text { nação, apresentando o conflito político e econômico entre norte e sul, o } \\
\text { desenvolvimento dos transportes, o potencial promissor de um território e } \\
\text { uma população em expansão e a política de forte proteção alfandegária. }\end{array}$ \\
$\begin{array}{l}\text { COMPLEMENTOS } \\
\text { AOS RELATOS DE } \\
\text { LIST }\end{array}$ & $\begin{array}{l}\text { Freeman (2008) acrescenta que, já na primeira metade do século XIX, } \\
\text { ocorreu uma intensificação de capital e capacitações organizacionais para } \\
\text { explorar a dimensão e a comunicação continental, iniciando-se a produção } \\
\text { e distribuição em larga escala. } \\
\text { Chang (2004), a partir do estudo do desenvolvimento de outras nações, } \\
\text { argumenta que a proteção tarifária tão elevada e persistente como a } \\
\text { verificada nos Estados Unidos não seria necessária. }\end{array}$
\end{tabular}

Fonte: Resultado da pesquisa.

\section{Considerações finais}

Verificou-se uma significativa similaridade entre os conteúdos apresentados por List $(1983,2009)$ e as interpretações de historiadores econômicos posteriores. Percebe-se que a descrição de List $(1983,2009)$ é menos detalhada em alguns aspectos do que a produção, por vezes mais específica e detalhada, dos demais autores. Há elementos adicionais nos relatos dos autores mais modernos consultados que, a despeito de sua importância para a composição de um quadro referencial histórico, não configuram a identificação de uma realidade radicalmente distinta. Tampouco há em List $(1983,1986)$ lacunas a ponto de descaracterizar o grau de desenvolvimento das nações.

List $(1983,2009)$ teve o acesso aos relatos de Hamilton (2009), leu suas considerações sobre a importância dos investimentos de capital estrangeiro, e inclusive escreveu sobre a importância da Costa Leste dos Estados Unidos como porta de entrada do capital intelectual e material vindo da Europa. No entanto, esta é uma afirmação circunscrita aos Estados Unidos; List (1983, 2009) deu maior ênfase aos óbices impostos pela Inglaterra 
ao desenvolvimento de outras nações do que a seu papel de difusora de técnicas produtivas e comerciais.

Entre os complementos aos relatos de List, está o que dá conta de que se, por um lado, a Inglaterra com suas Leis de Navegação, poder naval e abertura de importações de matérias-primas agrícolas procurava limitar o crescimento de outras nações, por outro, era fonte de transbordamento de conhecimentos produtivos e capital, bem como exemplo de sucesso com seu progresso industrial e sua estratégia comercial. Hobsbawm (1977) afirma isto reiteradas vezes e apresenta como exemplo a absorção de capital e de mão de obra especializada europeia pela parte norte dos Estados Unidos; Philip (1980) relaciona os investimentos iniciais em ferrovias na Alemanha a capitais ingleses; e Freeman (2008) exemplifica um caso de transbordamento de conhecimento da Inglaterra para os Estados Unidos (fiandeira hidráulica).

Atualmente, há evidências de que a proteção tarifária não era tão importante para o desenvolvimento nacional como supunha List (1983). Embora ele percebesse que o processo de constituição das forças produtivas era bem mais amplo e profundo do que uma política de restrições às importações, em sua percepção a magnitude elevada e de aplicação regular durante longo período seria fundamental. Os dados apresentados por Chang (2004) revelam, para o caso da Alemanha, que a magnitude das tarifas não é tão importante para o desenvolvimento econômico nacional.

A descrição de List $(1983,1986)$ sobre a evolução agrícola da Alemanha, embora corroborada em linhas gerais pelos demais autores, não é claramente referenciada no tempo. Em parte, isto se deve ao longo período de práticas feudais na organização da produção agrícola na Alemanha. Tilly (1978) e Philip (1980) proporcionam o acréscimo de informações objetivas, datadas, que permitem precisar que a agricultura esteve com sua produção condicionada a normativas feudais, principalmente no oeste da Alemanha, da Idade Média até a metade do século XIX. Em paralelo a isto, Philip (1980) informa que o setor industrial conservou essencialmente o regime do artesanato doméstico disperso pela província até 1860 . O regime de artesanato é superado nesta data concomitantemente à substituição da lã pelo algodão na tecelagem.

\section{Referências}

BIELSCHOWSKY, R. Cinquenta anos de pensamento da Cepal. Record, Rio de Janeiro, 2000.

BUARQUE, C. Apresentação. In: Sistema Nacional de Economia Política. Tradução: Luiz João Baraúna. 2. ed. São Paulo: Nova Cultural, 1979.

CASSIOLATO, J. E.; LASTRES, H. M. M.. Sistemas de inovação e desenvolvimento: as implicações de política. São Paulo em Perspectiva, v. 19, n. 1, p. 34-45, 2005.

CHANG, H. J. Chutando a escada. A estratégia do desenvolvimento em perceptiva histórica. Tradução: Luiz Antônio Oliveira de Araújo. São Paulo: Editora UNESP, 2004.

COSTA, F. N. Desenvolvimento do desenvolvimentismo: do socialismo utópico ao socialdesenvolvimentismo. Texto para discussão. Campinas: Instituto de Economia; Unicamp, Campinas, n. 205. 2012.

DEMO, P. Introdução à metodologia da ciência. 2. ed. Atlas: São Paulo, 2000.

FONSECA, P. C. D. O pensamento econômico alemão no século 19. In: HELFER, Inácio (Org.) Os pensadores alemães dos séculos XIX e XX. Santa Cruz do Sul: EDUNISC, 2000. p. 9-19.

FREEMAN, C. Technological infrastructure and international competitiveness. Industrial and Corporate Change, Oxford, v. 13, n. 3, p. 541-569, 2004. 
A economia da inovação industrial. Tradução: André Luiz Sica de Campos e Janaina Oliveira Pamplona da Costa. Campinas: Ed. Unicamp, São Paulo, 2008.

GEORGE, A. e BENNETT, A. Case studies and theory development in the social sciences. London; Cambridge: MIT Press, 2005.

HAMILTON, A.. Relatório sobre as manufaturas. In: HAMILTON, A; LIST, G. F; CAREY, H. Cartas da economia nacional contra o livre comércio. Tradução: José Lino Grünewald, J. Rodrigues. Rio de Janeiro: Capax Dei, 2009.

HOBSBAWM, Eric. J. A era do capital. 1848-1875. Tradução: Lilian Nunes da Costa. 3. ed. Rio de Janeiro: Paz e Terra, 1977.

A era das revoluções. Tradução: Maria Tereza Lopes Teixeira e Marcos Penchel. 24. ed. Ed. Rio de Janeiro: Paz e Terra, 1977.

LIST, G. F. The national system of Political Economy. Tradução: Sampson S. Lloyd. 2 ed. 1845.

Sistema nacional de Economia Política. Tradução: Luiz João Baraúna. São Paulo: Nova Cultural, 1983.

Sistema nacional de Economia Política. Tradução: Luiz João Baraúna. 2 ed. São Paulo: Abril Cultural, 1986.

LIST, G. F. Esboço de Economia Política Americana. In: HAMILTON, A; LIST, G. F; CAREY, $H$. Cartas da economia nacional contra o livre comércio. Tradução: José Lino Grünewald, J. Rodrigues. Rio de Janeiro: Capax Dei, 2009.

PEREIRA, L. M. P.; MENEZES, S. L. Sobre ideias e instituições: a riqueza das nações ou a riqueza da nação? As ideias de Adam Smith e Friedrich List sobre o desenvolvimento do capitalismo. Acta Scientiarum. Human and Social Sciences, v. 30, n. 1, 30 set. 2008.

PHILIP, A. L. História dos factos económicos e sociais. 2. ed., Lisboa: Moraes Editores, 1980.

SCHUMPETER, J. A teoria do desenvolvimento econômico. São Paulo: Abril Cultural, 1982.

TILLY, R. H. T. The Cambridge Economic History of Europe; Capital Formation in Germany in the Nineteenth Century. Ch. 3. New York: Cambridge University Press, 1978.

Recebido em agosto de 2018. Aprovado em dezembro de 2018. 